\title{
Fasilitas Ruang Khusus pada Sekolah Inklusi Binar Indonesia (Bindo) di Bandung
}

\author{
Mamiek Nur Utami' ${ }^{1}$, Wahyu Buana Putra ${ }^{1}$ \\ ${ }^{1}$ Program Studi Arsitektur, Fakultas Arsitektur dan Desain, \\ Itenas, Institut Teknologi Nasional Bandung \\ Email: mam@itenas.ac.id
}

\begin{abstract}
ABSTRAK
Diterbitkannya Rencana Induk Pengembangan Pendidikan Inklusif Tingkat Nasional Tahun 2019 - 2024, memperkuat keinginan pemerintah dalam membuat konsep sekolah pendidikan inklusi. Sekolah Inklusi merupakan sebuah pelayanan pendidikan dimana Anak Berkebutuhan Khusus (ABK) belajar bersama satu ruang dengan anak normal. Mereka belajar bersama, meskipun kemungkinan materi yang diberikan berbeda. Saat ini belum ada standar fasilitas kebutuhan ruang untuk sekolah inklusi. Penelitian ini menganalisa kebutuhan ruang, persyaratan ruang sekolah yang dapat mendukung proses belajar pada sekolah inklusi. Analisa kebutuhan ruang untuk sekolah inklusi ini berdasarkan karakteristik umum yang terdapat pada anak lamban belajar, kesulitan belajar, autis dan Attention Deficit Hyperactive Disorder (ADHD). Metode yang dipakai pada penelitian ini adalah metodologi kualitatif deskriptif. Hasil dari penelitian ini menunjukkan bahwa sekolah inklusi harus memiliki ruang-ruang khusus yang merupakan bagian dari penanganan anakanak berkebutuhan khusus, ruang tersebut memiliki persyaratan ruang yang spesifik sesuai dengan karaktek anak yang ditangani. Ruang khusus tersebut diantaranya: (a) Ruang Belajar Individu yang digunakan untuk anak belajar bersama guru secara individual atau bisa juga secara kelompok dengan jumlah siswa terbatas, yaitu maksimum 5 siswa, (b) Ruang Renung dibutuhkan untuk anak yang sedang mengamuk atau tantrum berat, (c) Ruang konsultasi dipergunakan untuk orang tua berkonsultasi dengan guru, psikolog dan pedagog di sekolah.
\end{abstract}

Kata kunci: inklusi, anak berkebutuhan khusus (ABK), metode kualitatif deskriptif, ruang-ruang khusus.

\begin{abstract}
The issuance of the National Level Inclusive Education Development Master Plan for 2019-2024, strengthens the government's desire to conceptualize inclusive education schools. Inclusive School is an educational service where children with special needs $(A B K)$ study in one room with normal children. They studied together, even though the material might be different. Currently, there are no standard facilities for the space requirements for inclusive schools. This study analyzes space requirements and school space requirements that can support the learning process in inclusive schools. The analysis of space requirements for inclusive schools is based on general characteristics found in slow learners, learning difficulties, autism and Attention Deficit Hyperactive Disorder (ADHD). The method used in this research is descriptive qualitative methodology. The results of this study indicate that inclusive schools must have special rooms which are part of the handling of children with special needs, these spaces have specific space requirements in accordance with the characteristics of the children being handled. These special rooms include: (a) Individual Study Rooms which are used for children to study with the teacher individually or in groups with a limited number of students, namely a maximum of 5 students, (b) The Reflection Room is needed for children who are raging or heavy tantrums, (c) The consultation room is used for parents to consult with teachers, psychologists and pedagogues in schools.
\end{abstract}

Keywords: inclusive, special needs student, descriptive qualitative method, special rooms 


\section{PENDAHULUAN}

Pada prinsipnya setiap anak mempunyai hak dan wajib mengikuti pendidikan (amanah UUD 1945 pasal 31), demikian juga anak-anak berkebutuhan khusus. Anak berkebutuhan khusus dapat mengikuti pelajaran disekolah khusus atau luar biasa yang disediakan oleh pemerintah maupun swasta namun terdapat beberapa perbedaan fasilitas maupun pembelajaran yang tersedia disekolah khusus dibandingkan sekolah umum. Sebagian orang tua memasukkan anaknya disekolah umum, untuk memecahkan masalah tersebut dan sebagian sekolah umum menerima anak berkebutuhan khusus (ABK). Anak-anak yang berkebutuhan khusus, memerlukan suatu metode pembelajaran yang sifatnya khusus. Suatu pola gerak yang bervariasi, diyakini dapat meningkatkan potensi peserta didik dengan kebutuhan khusus dalam kegiatan pembelajaran (berkaitan dengan pembentukan fisik, emosi, sosialisasi, dan daya nalar) [10]. Saat ini terdapat sekolah umum yang menerima anak berkebutuhan khusus yang disebut dengan Sekolah Inklusi. Sekolah Inklusi merupakan sebuah pelayanan pendidikan dimana peserta didiknya ada yang berkebutuhan khusus.

Terdapat tiga hal penting yang terdapat di dalam diri individu dan akan mempengaruhi kehidupannya, diantaranya aspek kognitif, aspek afektif, dan aspek psikomotorik. Pada bidang pendidikan, ketiga hal tersebut akan terwujud di dalam bidang akademik, kepribadian individu serta keterampilan yang dimiliki. Selain itu tiga hal penting diatas menjadi aspek penilaian peserta didik di sekolah, yang menjadi bagian penentu keberhasilan bagi seorang peserta didik. [9]

Sekolah inklusi dapat dimulai dari jenjang pendidikan Kelompok Bermain, Taman Kanak-kanak, Sekolah Dasar, Sekolah Menengah Pertama dan Sekolah Menengah Atas. Jumlah sekolah inklusi masih sedikit, hal ini disebabkan karena untuk menyelenggarakan sekolah inklusi, sekolah harus menyediakan, pedagog yang mengetahui dan memahami pendidikan anak berkebutuhan khusus, alat peraga pendidikan untuk anak berkebutuhan khusus, dan ruang-ruang khusus yang diperlukan untuk anak berkebutuhan khusus. Sampai dengan saat ini Dinas Pendidikan belum mengeluarkan pedoman tentang standar fasilitas ruang untuk sekolah inklusi, namun hanya mempunyai standar fasilitas ruang untuk sekolah umum.

Menurut Peraturan menteri Pendidikan no 24 th 2007 persyaratan fasilitas ruang yang harus tersedia adalah: (a) ruang kelas, (b) ruang perpustakaan, (c) laboratorium IPA, (d) ruang pimpinan, (e) ruang guru, (f) tempat beribadah, (g) ruang UKS, (h) kamar mandi/ toilet, (i) gudang, (j) ruang sirkulasi, (k) tempat bermain/berolahraga. Sekolah Binar Indonesia atau yang dikenal dengan BINDO adalah sekolah inklusi karena di sekolah tersebut terdapat 15 anak berkebutuhan khusus. Berdasarkan pemeriksaan dokter spesialis anak, menyatakan bahwa anak-anak berkebutuhan khusus yang berada di Sekolah BINDO, dikategorikan sebagai anak yang lamban belajar, kesulitan belajar, autis dan ADHD. Perlu diketahui bahwa setiap jenis kebutuhan khusus mempunyai ciri yang khas, yang sudah dapat terdeteksi sejak umur dibawah tiga tahun. Diperlukan terapi sejak anak masih kecil atau berumur dibawah tiga tahun untuk memperkecil disabilitasnya.

Pada perkembangannya pendidikan inklusi memiliki beberapa pengertian yang berbeda, yaitu : Special Education, Pendidikan Integratif, dan Pendidikan Bagi Anak Berkebutuhan Khusus. Terdapat banyak definisi pendidikan inklusi yang berkembang dimasyarakat, hal ini tergantung pada interpretasi masyarakat. Istilah yang berkembang terkadang salah atau misinterpretation, seperti sebuah sekolah dapat disebut melaksanakan pendidikan inklusi salah satunya dengan melaksanakan kelas segregatif yang terdapat didalamnya anak dengan indikasi perilaku bermasalah.

Partisipasi seluruh tenaga pengajar dengan kualifikasi khusus menjadi sangat penting dalam melaksanakan sekolah inklusi. Jenis terapi yang diberikan untuk setiap anak berkebutuhan khusus, tergantung dari jenis kebutuhan khususnya dan juga tergantung tingkat berat tidaknya kebutuhan khusus tersebut. Oleh karena itu, harus diketahui terlebih dahulu ciri khas dari setiap kelainan [1].

Anak yang mempunyai intelektual quotient (IQ) atau tingkat kecerdasan 90, mereka tidak mempunyai kelainan perilaku dan kelainan emosional merupakan ciri khas anak lamban belajar. Sedangkan karakter khusus anak kesulitan belajar adalah anak yang mempunyai suatu gangguan dalam satu atau lebih proses 
psikologis yang mencakup pemahaman dan penggunaan bahasa, ujaran atau tulisan. Gangguan tersebut mungkin terlihat dalam bentuk kesulitan mendengarkan, berpikir, berbicara, membaca, menulis, mengeja, atau berhitung. Batasan tersebut tidak mencakup anak-anak yang memiliki masalah belajar yang penyebab utamanya berasal dari adanya hambatan dalam penglihatan, pendengaran, motorik, hambatan karena tunagrahita, karena gangguan emosional, atau karena kemiskinan lingkungan, budaya, atau ekonomi. Anak kesulitan belajar bukan anak yang bodoh, bisa jadi mereka pintar, tapi karena sesuatu hal, mereka menjadi sulit untuk mengerti pelajaran.

Anak autis merupakan anak yang memiliki gangguan pada proses perkembangan syaraf yang kompleks hal ini ditandai dengan kesulitan individu saat melakukan interaksi sosial, komunikasi, dan pola perilaku yang terbatas, selalu berulang-ulang dan memiliki karakter stereotip. Pada umumnya indikasi autis akan muncul sebelum anak menginjak 3 tahun sejak anak dilahirkan. Anak berkebutuhan khusus dengan karakter autisme merupakan salah satu dari tiga gangguan Autism spectrum disorder. Adapun dua di antaranya adalah sindrom Asperger dan PDD-NOS (pervasive developmental disorder, not otherwise specified). Autisme dapat dikelompokkan dalam 3 kelompok, yaitu:

a. Autisme sangat ringan. Memiliki fungsi kognitif dan intelegensi yang tinggi, mampu menggunakan bahasa dan bicaranya secara efektif serta menunjukan kemampuan mengikuti rutinitas, diklasifikasikan sebagai high functioning autism, sehingga masyarakat tidak menyadari seluruh keberadaannya. Biasanya mereka bisa memasuki perguruan tinggi.

b. Autisme sedang. Memiliki tingkat intelegensi dan kognitif yang baik, berbicara dengan baik dan menunjukan minat, tetapi mereka mempunyai kelainan perilaku dan emosi. Sehingga kemampuan belajarnya terganggu oleh kelainan perilaku dan emosi tersebut

c. Autisme berat. Memiliki tingkat intelegensi dan kognitif yang rendah, tidak berbicara (non verbal), sering kali memiliki perilaku menyakiti diri sendiri, serta menunjukkan terbatasnya minat dan rutinitas yang dilakukan. Biasanya diklasifikasikan sebagai low functioning autism.

Tingkat kelainan autisme berpengaruh pada implikasi pendidikan maupun model terapi yang diberikan. Sehingga untuk pendidikannya diperlukan pendidikan dengan program individual atau program belajar dengan jumlah siswa terbatas, misal 1 kelompok terdiri dari 5 siswa. Anak penyandang autisme, istilah sembuh tidak ada; yang terjadi adalah mengurangi perilaku autisme. Untuk mengurangi perilaku autisme diperlukan terapi khusus, misalnya terapi prilaku, terapi sensori integration, terapi bicara, dll, tergantung dari berat ringannya tingkat autisme. Selain itu untuk yang mempunyai kelainan perilaku harus sering diintervensi atau diingatkan agar mereka tak melakukan perilaku yang tak baik. Sehingga diharapkan mereka tidak melakukan lagi perilaku yang tak baik tersebut.

Karakter anak dengan gejala Attention Deficit Hyperactive Disorder (ADHD) adalah anak yang mempunyai kesulitan berkosentrasi karena perhatiannya selalu beralih dan selalu bergerak untuk menarik perhatian dan biasanya mereka tak dapat mengontrol emosi, sangat impulsive. Setelah dewasa, mereka sulit untuk mengatur waktu, sulit untuk mengorganisir sesuatu, menentukan tujuan, mempertahankan pekerjaannya dan mengadakan hubungan relationships dengan orang lain. ADHD ditandai oleh 3 gejala utama yaitu inatensi, hiperaktivitas, dan impulsivitas. Gejala yang satu bisa jadi menonjol dibandingkan gejala lainnya, atau bisa juga terjadi kombinasi dari gejala-gejala tersebut.

Akibat adanya kebutuhan khusus pada anak-anak dengan ciri diatas yang dapat dikategorikan sebagai suatu keadaan anak dengan kondisi mental yang memerlukan perlakuan khusus terlihat pada segala aktivitas mengalami keterlambatan dan ketidakseimbangan didalam segala aspek. Tantangan membimbing anak berkebutuhan khusus sebagai wujud dari hambatan yang dimilikinya akan menciptakan ruang-ruang aktivitas belajar yang khusus sesuai dengan karakter anak-anak berkebutuhan khusus. 


\section{METODOLOGI}

Metoda penelitian yang dipakai adalah metoda penelitian kualitatif deskriptif, yaitu prosedur pemecahan masalah yang diselidiki dengan menggambarkan keadaan sebenarnya dan fakta-fakta yang terjadi pada lingkup penelitian. Lokasi penelitian ini berada di Sekolah Binar Indonesia yang merupakan Sekolah yang terletak di wilayah Bandung Timur, tepatnya di Jalan Rancabolang No. 241 Bandung. Sekolah tersebut merupakan salah satu sekolah inklusif di Bandung yang menerima anak berkebutuhan khusus dengan kriteria tertentu. Penelitian ini mengambil setting tiga ruang yang akan menjadi fokus penelitian sebagai ruang khusus yang terbentuk akibat dari karakter khusus anak berkebutuhan khusus di Sekolah BINDO.

Terdapat sepuluh klasifikasi dan karakter anak berkebutuhan khusus, diantaranya: (a) Anak Kesulitan Belajar (Learning Disabilities) atau anak berprestasi rendah (spesific learning disability); (b) Tunarungu Wicara (Communication Disorder and Deafness); (c) Hyperactive (Attention Deficit Disorder with Hyperactive); (d) Tunanetra (Partially Seing and Legally Blind); (e) Tunalaras (Emotional or Behavioral Disorder); (f) Tunarungu Wicara (Communication Disorder and Deafetess); ( $g$ ) Autistik (Autustic Child); (h) Anak Tunadaksa atau Anak dengan Hendaya Fisik Motorik (Physical Disability); (i) Karakteristik Anak Tuna Ganda (Multiple Handicapped); (j)Anak Berbakat dan Berkebutuhan (Giftness and Special Tallented) [2]. Sekolah BINDO menerima empat karakter anak berkebutuhan khusus, dari sepuluh yang telah disebutkan diatas, diantaranya : (a) Anak Lamban Belajar; (b) Kesulitan Belajar; (c) Autis; (d) Attention Deficit Hyperactive Disorder (ADHD). [2]

Proses peroleh data pada penelitian ini dilakukan dengan cara :

1. Survey lapangan, pengukuran dimaksudkan untuk mengidentifikasi bagaimana cara pelaksanaan proses belajar mengajar untuk anak-anak berkebutuhan khusus.

2. Dokumentasi dan pengamatan tentang perilaku dan karakter berkebutuhan khusus. anak lamban belajar, kesulitan belajar, autis dan ADHD.

3. Studi literatur, agar mendapatkan hasil yang sesuai, maka data-data yang didapat harus merujuk pada studi literatur yang terkait dengan perilaku dan karakter disabilitasnya.

4. Proses penelitian dilakukan selama 6 bulan.

Sekolah BINDO menerima siswa didik normal dan siswa didik berkebutuhan khusus, sehingga ruangruang yang ada disekolah tersebut merepresentasikan karakter penanganan anak berkebutuhan khusus, apabila ternyata ruang yang dibutuhkan tidak terdapat pada Standar Persyaratan Fasilitas ruang yang harus disediakan sesuai dengan Peraturan menteri Pendidikan no 24 th 2007, maka ruang tersebut harus disediakan [2]. Setiap anak memiliki karakter dan perilaku yang berbeda, untuk mencegah kelainan pada perkembangan anak biasa pihak sekolah akan melakukan pendeteksian dini terhadap perkembangan anak, adapun tahapan atau alur pendeteksian dini tumbuh kembang anak dapat dilihat pada (Gambar 2.1).

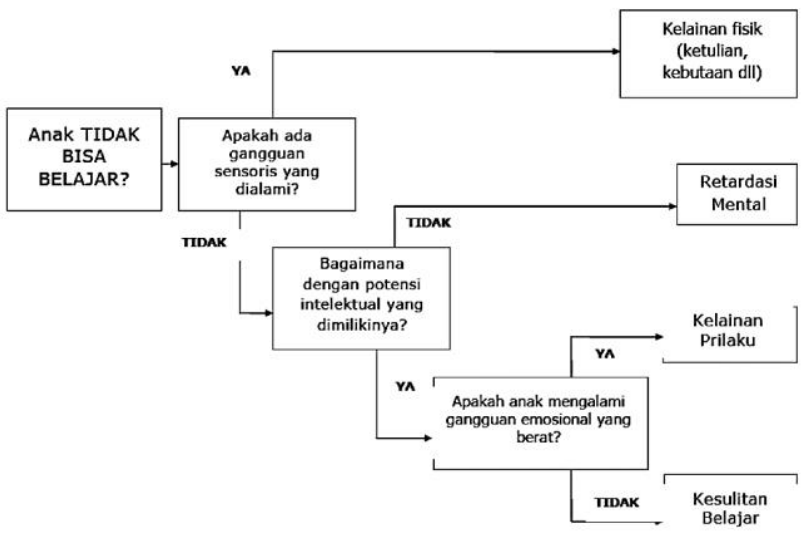

Gambar 2.1, Alur Deteksi Dini Tumbuh Kembang Anak Sumber : Zaitun, 2017 


\section{HASIL DAN PEMBAHASAN}

Ruang belajar di sekolah biasanya disebut kelas namun tidak menutup kemungkinan ruang belajar tersebut bisa dilakukan di ruang terbuka, misalnya taman bermain, sawah, hutan dan kebun, hal ini memberikan arti bahwa aktivitas belajar bisa dilakukan dimana saja. Meskipun demikian, agar siswa dapat menerima pelajaran dengan baik salah satu ketentuan yang harus dipenuhi antara lain diperlukan suasana yang tenang dan tak ada keributan.

Tabel 3.1. Perbandingan Fasilitas Ruang Sekolah

\begin{tabular}{|c|c|}
\hline \multicolumn{2}{|c|}{ Sarana dan Prasarana Sekolah } \\
\hline Permen 24 Tahun 2007 & Sekolah BINDO \\
\hline - Ruang Kelas, & - Ruang Kelas, \\
\hline - Ruang Perpustakaan, & - Ruang Perpustakaan, \\
\hline - Laboratorium Ipa, & - Laboratorium Ipa, \\
\hline - Ruang Pimpinan, & - Ruang Pimpinan, \\
\hline - Ruang Guru, & - Ruang Guru, \\
\hline - Tempat Beribadah, & - Tempat Beribadah, \\
\hline - Ruang Uks, & - Ruang Uks, \\
\hline - Jamban, & - Jamban, \\
\hline - Gudang, & - Gudang, \\
\hline - Ruang Sirkulasi, & - Ruang Sirkulasi, \\
\hline - Tempat Bermain/Berolahraga. & - Tempat Bermain/Berolahraga \\
\hline & - $\quad$ Ruang Individu \\
\hline & - Ruang Renung \\
\hline & - Ruang Komunikasi/ Konsultasi \\
\hline
\end{tabular}

Tabel 3.1 diatas memperlihatkan bahwa berdasarkan Permen 24 Tahun 2007, terdapat sarana dan prasarana sekolah yang wajib dipenuhi oleh sebuah sekolah pada umumnya. Sekolah BINDO sebagai sekolah inklusi yang menerima siswa didik normal dan siswa didik berkebutuhan khusus memiliki tiga ruang tambahan sebagai ruang pelengkap untuk memberikan pelayanan khusus pada anak berkebutuhan khusus.

\subsection{Ruang Belajar Anak Lamban Belajar}

Anak Lamban Belajar tidak mempunyai kelainan perilaku dan emosional, sehingga bisa beradaptasi di kelas. Anak dengan kategori ini memerlukan waktu belajar yang lebih lama dari pada anak normal, hal ini menuntut perhatian khusus dari pengajar. Anak Lamban Belajar memiliki ciri diantaranya: (a) kemampuan anak dibawah rata-rata kelas, (b) Prestasi belajar rata-rata selalu rendah, (c) Penyelesaian tugas sering terlambat dibandingkan teman-teman seusianya. (d) Daya tangkap pada materi pelajaran lambat. (e) Membutuh waktu yang lama dan selalu berulang-ulang untuk menyelesaikan tugas akademik dan non akademik, (f) Lebih menyenangi bergaul dengan anak yang berusia jauh di bawahnya [7]. Anak dengan kategori Lamban Belajar jika digabungkan kedalam satu kelas dengan anak normal, maka jumlah siswa dalam satu kelasnya harus sedikit, agar psikologis anak tersebut tetap terjaga. Idealnya Anak Lamban Belajar pada mata pelajaran tertentu, dipisah dengan anak normal, dengan demikian mereka dapat belajar di ruang belajar individu atau kelompok kecil dengan anggota kelompok maksimal 5 orang saja. (Lihat Gambar 3.1).

\subsection{Ruang Belajar Anak Kesulitan Belajar}

Anak kesulitan belajar ada beberapa jenis yaitu DHD (deficit hyperactive disorder), ADD (Attention deficit disorder), Dyslexia, Dysgraphia, Dyscalculia, Dysphasia, Dyspraxia, merupakan kelainan yang tidak disertai dengan gangguan emosi, tetapi anak dengan kategori ini tetap memerlukan ruang khusus, karena memerlukan metoda pembelajaran semi individual atau mereka memerlukan perhatian yang khusus. Sehingga Anak Kesulitan Belajar memerlukan kelas individual. Pada anak diusia Taman Kanak 
Kanak, belum memperlihatkan gejala kelainan kesulitan belajar, karena pada tingkat Taman Kanak Kanak pembelajarannya dengan bermain. Namun pada anak dysphasia (terlambat bicara), anak dyspraxia (kelainan motorik), anak DHD (deficit hyperactive disorder) sudah dapat terdeteksi.
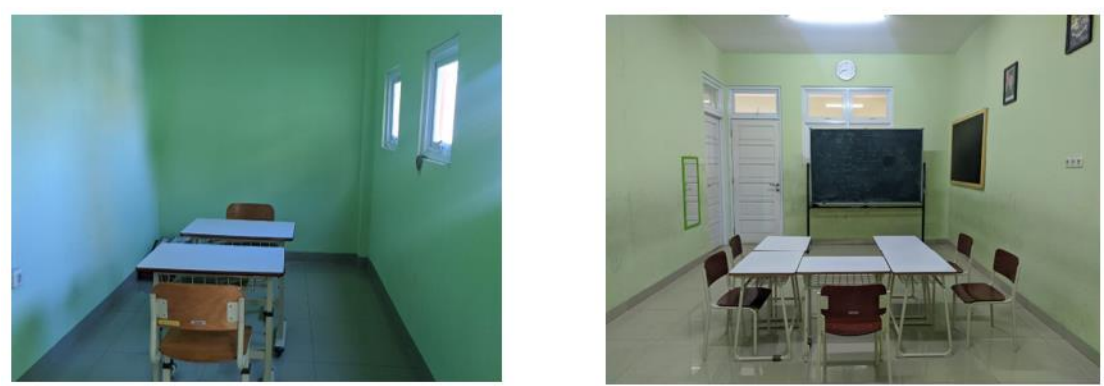

Gambar 3.1, Ruang Belajar Kelompok Kecil atau Individu

Sumber: Sekolah BINDO, 2020

\subsection{Ruang Belajar Anak Autis}

Autisme merupakan gangguan yang meliputi area kognitif, emosi, perilaku, sosial, termasuk juga ketidakmampuan untuk berinteraksi dengan orang-orang di sekelilingnya [8]. Anak berkebutuhan khusus dengan karakteristik autistik antara lain adalah kelainan perilaku, misalnya mereka mengetuk meja berulang kali, menggerakan angota badannya berulang-ulang atau berbicara tanpa henti. Perilaku khusus ini tidak terjadi secara konstan atau tetap dan pada waktu spesifik, namun terjadi tiba-tiba dengan waktu yang tidak diduga. Pada saat anak autis mengalami perilaku khusus seperti ini, anak tersebut akan dipisahkan dengan kelompok belajar anak normal karena bisa mengganggu kenyamanan kelas, maka pada saat itulah anak dibawa ke ruang belajar individu. Selain perilaku khusus, mereka mempunyai kelainan emosional, sehingga terkadang mengamuk atau tantrum. Hal tersebut terjadi apabila anak tidak merasa nyaman di lingkungannya atau merasakan ada yang sakit. Pada keadaan seperti itu, anak tersebut harus dibawa keluar ruang kelas yang berbeda agar tidak mengganggu suasana di ruang kelas.

Anak dengan kondisi diatas harus diberikan rasa tenang, dengan membawanya kedalam ruang khusus yang disebut dengan Ruang Renung atau Ruang Tenang, selama berada di Ruang Renung harus tetap didampingi bersama Guru Pendamping Khusus. Pada Sekolah Tingkat Taman Kanak Kanak yang aktivitasnya lebih banyak bermain, maka fasilitas ruang tambahan hanya ruang untuk menenangkan diri (Ruang Renung). Sedangkan untuk Sekolah Dasar dengan aktivitas yang lebih banyak belajar, maka ruang tambahannya tidak hanya Ruang Renung, namun ditambah dengan Ruang Belajar Individu.

\subsection{Ruang Belajar Anak Attention Deficit/ Hyperactive Disorder (ADHD).}

Kelainan anak ADHD sudah dapat terlihat pada umur dini yaitu 3 tahun, dengan cara mendeteksi perilakunya yang tidak mau diam, rewel dan suka mengganggu temannya, tetapi hal tersebut harus diwaspadai, apakah kelainan itu hanya sementara atau menetap. Kelainan menetap adalah kelainan yang terjadi sejak lahir, sedangkan kelainan sementara adalah respon anak terhadap pola asuh yang diberikan di rumah. Sehingga dalam hal ini guru harus mengetahui bagaimana keadaan keseharian anak, untuk mengetahui hal tersebut guru harus mengunjungi tempat tinggal anak, kunjungan ini disebut "home visit". Hasil kunjungan tersebut didiskusikan dengan orang tua siswa, proses komunikasi dua arah dan dilakukan dengan suasana kekeluargaan akan berperan penuh pada perubahan perkembangan anak dengan gejala ADHD menjadi lebih baik.

Anak ADHD sering mengamuk atau tantrum, hal ini terjadi karena anak tersebut belum bisa mengendalikan emosinya, sehingga membuat lingkungan tidak nyaman untuk proses pembelajaran. Oleh karena itu anak tersebut harus dibawa ke sebuah ruang lain, sehingga tak mengganggu proses belajar di kelas. Selama anak tantrum, anak tersebut membutuhkan ruang yang tenang, aman, nyaman dan suasana hangat yang ditemani guru pendamping, sehingga proses pendekatan dan komunikasi dapat terjalin. Hal ini harus dilakukan untuk menghindari perbuatan tantrum ditiru oleh anak yang lain, atau untuk menghindari perundungan yang dilakukan anak normal ke anak berkebutuhan khusus. Didalam kelas biasanya anak ADHD selalu bergerak berlebihan atau mengeluarkan kata kata yang tidak relevan 
dengan suasana kelas, bila hal itu terjadi maka suasana kelas menjadi tak nyaman untuk belajar. Sehingga pada saat tersebut anak ADHD tersebut harus dipisahkan dengan kelas belajar normal. Selanjutnya dibawa untuk belajar secara individu dengan ditemani guru pendamping di ruang belajar individu. Belajar diruang individu, bisa diartikan belajar sendiri bersama guru atau belajar bersama dengan kelompok kecil, maksimum lima siswa perkelompok bersama dengan dua guru pendamping.

Proses perubahan anak ADHD tidak hanya bisa dilakukan sepihak atau di sekolah saja namun pendidikan di rumah harus satu visi dengan pendidikan disekolah. Agar terciptanya visi yang sama, proses komunikasi dengan orang tua siswa harus dilakukan dengan suasana ruang yang nyaman dan kekeluargaan, sehingga diperlukan Ruang Komunikasi atau Konsultasi. Suasana berbeda ketika proses komunikasi ini dilakukan di ruang rapat atau ruang kelas disekolah, rasa nyaman, kekeluargaan tidak dapat tercipta didalam ruang formal tersebut, dengan demikian keberadaan ruang khusus yang berfungsi sebagai ruang konsultasi atau komunikasi di sekolah inklusi memiliki peran yang sangat penting.

Sesuai dengan hasil analisa di atas, didapatkan bahwa sebuah sekolah inklusi yang menangani anak berkebutuhan khusus harus menyediakan: (a) ruang renung yang berfungsi sebagai penenang diri, (b) ruang belajar individu yang berfungsi sebagai pemisah ketika gejala perilaku khusus pada anak berkebutuhan khusus muncul, (c) ruang konsultasi yang nyaman dan kekeluargaan. Tiga ruang tersebut belum diatur dan menjadi persyaratan fasilitas ruang seperti yang tertera pada Peraturan Menteri Pendidikan no 24 th 2007, sebagai bagian dari sarana dan prasarana kelengkapan bangunan sekolah [3].

\subsection{Persyaratan Ruang dan Disain Ruang.}

Pada dasarnya kenyamanan ruang jika ditinjau dalam konteks arsitektur terdiri dari: kenyamanan ruang (spatial comfort), kenyamanan penglihatan (visual comfort), kenyamanan pendengaran (audial comfort), dan kenyamanan termal (thermal comfort).

Tabel 3.2. Persyaratan Ruang

\begin{tabular}{|c|c|c|c|c|c|}
\hline $\begin{array}{l}\text { Nama } \\
\text { Ruang }\end{array}$ & $\begin{array}{l}\text { Fungsi } \\
\text { Ruang }\end{array}$ & $\begin{array}{l}\text { Kenyamanan } \\
\text { Ruang }\end{array}$ & $\begin{array}{l}\text { Kenyama } \\
\text { nan } \\
\text { Penglihata } \\
\text { n }\end{array}$ & $\begin{array}{l}\text { Kenyamanan } \\
\text { Pendengaran }\end{array}$ & $\begin{array}{c}\text { Kenyamana } \\
\mathrm{n} \text { Thermal }\end{array}$ \\
\hline $\begin{array}{l}\text { Ruang } \\
\text { Renung } \\
\text { (Ruang } \\
\text { Tenang) }\end{array}$ & $\begin{array}{l}\text { Menenangka } \\
\text { n ABK yang } \\
\text { mengamuk. }\end{array}$ & $\begin{array}{l}\text { Kapasitas } 1 \text { ABK, } 2 \\
\text { guru. } \\
\text { Kebutuhan ruang } \\
\text { perorang } 2 \mathrm{~m}^{2} \\
\text { ABK dalam posisi } \\
\text { berbaring. } \\
\text { Tak boleh ada } \\
\text { elemen ruang yang } \\
\text { tajam atau runcing. } \\
\text { Sifat ruang privat, } \\
\text { intim. }\end{array}$ & $\begin{array}{l}250-300 \\
\text { lux } \\
\text { menurut } \\
\text { SNI untuk } \\
\text { sekolah }\end{array}$ & $\begin{array}{l}\text { Tingkat kebisingan } \\
55 \text { dBA. } \\
\text { (Keputusan } \\
\text { Menteri Negara } \\
\text { Lingkungan Hidup } \\
\text { KEP- } \\
\text { 48/MENLH/11/199 } \\
\text { 6) } \\
\text { Bila perlu } \\
\text { diperdengarkan } \\
\text { suara musik yang } \\
\text { membuat ABK } \\
\text { tenang. }\end{array}$ & $\begin{array}{l}\text { Suhu } \\
\text { nyaman } \\
\text { optimal } \\
\text { antara } 22,8 \text { - } \\
25,8^{\circ} \mathrm{C}\end{array}$ \\
\hline $\begin{array}{l}\text { Ruang } \\
\text { belajar } \\
\text { individu }\end{array}$ & Belajar & $\begin{array}{l}\text { Kapasitas } 5 \text { ABK, } 1 \\
\text { guru dan } 1 \text { guru } \\
\text { pendamping } \\
5 \text { meja dan kursi } \\
\text { ABK } \\
1 \text { meja dan kursi } \\
\text { guru } \\
\text { Privat, intim }\end{array}$ & $\begin{array}{l}250-300 \\
\text { lux } \\
\text { menurut } \\
\text { SNI }\end{array}$ & $\begin{array}{l}\text { Tingkat kebisingan } \\
55 \text { dBA. } \\
\text { (Keputusan } \\
\text { Menteri Negara } \\
\text { Lingkungan Hidup } \\
\text { KEP- } \\
\text { 48/MENLH/11/199 } \\
6 \text { ) }\end{array}$ & $\begin{array}{l}\text { Suhu } \\
\text { nyaman } \\
\text { optimal } \\
\text { antara } 22,8 \text { - } \\
25,8^{\circ} \mathrm{C}\end{array}$ \\
\hline
\end{tabular}




\begin{tabular}{|c|c|c|c|c|c|}
\hline $\begin{array}{l}\text { Nama } \\
\text { Ruang }\end{array}$ & $\begin{array}{l}\text { Fungsi } \\
\text { Ruang }\end{array}$ & $\begin{array}{l}\text { Kenyamanan } \\
\text { Ruang }\end{array}$ & $\begin{array}{c}\text { Kenyama } \\
\text { nan } \\
\text { Penglihata } \\
n\end{array}$ & $\begin{array}{l}\text { Kenyamanan } \\
\text { Pendengaran }\end{array}$ & $\begin{array}{c}\text { Kenyamana } \\
\mathrm{n} \text { Thermal }\end{array}$ \\
\hline $\begin{array}{l}\text { Ruang } \\
\text { Komunikas } \\
\text { i/ } \\
\text { Konsultasi }\end{array}$ & $\begin{array}{l}\text { Orang tua } \\
\text { berkonsultas } \\
\text { i dengan } \\
\text { psikolog, } \\
\text { guru atau } \\
\text { pedagog }\end{array}$ & $\begin{array}{l}\text { Kapasitas } 4 \text { orang } \\
1 \text { set sofa } \\
\text { Privat }\end{array}$ & $\begin{array}{l}250-300 \\
\text { lux } \\
\text { menurut } \\
\text { SNI }\end{array}$ & $\begin{array}{l}\text { Tingkat kebisingan } \\
55 \text { dBA. } \\
\text { (Keputusan } \\
\text { Menteri Negara } \\
\text { Lingkungan Hidup } \\
\text { KEP- } \\
\text { 48/MENLH/11/199 } \\
6 \text { ) }\end{array}$ & $\begin{array}{l}\text { Suhu } \\
\text { nyaman } \\
\text { optimal } \\
\text { antara } 22,8 \text { - } \\
25,8^{\circ} \mathrm{C}\end{array}$ \\
\hline
\end{tabular}

Ruang belajar kelompok kecil atau individu, dibuat sedemikian rupa agar terbentuk suasana ruang intim sehingga dimensi ruang yang digunakan adalah dimensi dengan jarak intim yaitu fase dekat $0.00-0.15$ meter dan fase jauh $0.15-0.50$ meter. Desain ruang dengan jarak intim akan memungkinkan proses komunikasi dengan sentuhan dan komunikasi yang cukup dengan suara pelan lirih penuh kasih sayang[5]. Ruang belajar individu didesain dengan dimensi 3x4 meter atau 12 meter persegi dengan kapasitas maksimal lima siswa dan dua guru pendamping membuat aktivitas gerak antar individu dapat dilakukan dengan jarak intim

Penataan perabot harus sedemikian rupa menciptakan suasana ruang intim, tidak ada lukisan atau gambar yang mengganggu konsentrasi, sehingga siswa dapat berkonsentrasi dan fokus kepada guru pendamping. Ruang didesain dengan tetap memperhatikan kenyamanan sirkulasi udara dan pencahayaan namun tetap memperhatikan sisi keamanan dan kenyamanan serta konsentrasi siswa berkebutuhan khusus, sehingga posisi tinggi jendela harus sedemikian rupa tidak terjangkau tangan maupun visual dari luar maupun dari dalam. Posisi ambang bawah jendela dengan ketingian 1,75 meter tidak terjangkau oleh tangan dan pandangan anak-anak, sehingga dapat mencegah terjadinya pemukulan kaca jendela yang membahayakan. Selanjutnya ruang belajar individu juga harus menggunakan warnawarna yang netral maupun warna-warna yang memberikan ketenangan perasaan. (Gambar 3.2)
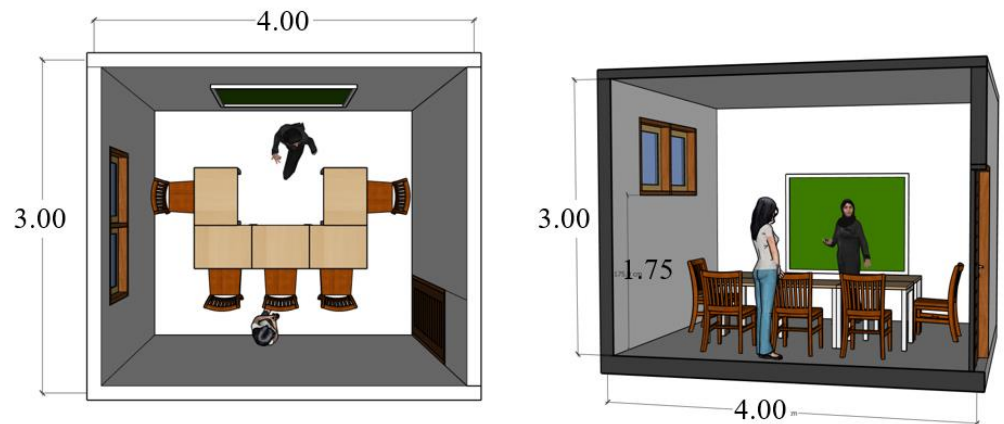

Gambar 3.2, Ruang Belajar Kelompok Kecil atau Individu Sumber : Hasil analisis, 2020

Ruang renung, merupakan ruang yang digunakan untuk siswa menenangkan diri dengan didampingi oleh guru pemdamping khusus. Ruang renung harus harus aman untuk anak, tidak boleh terdapat tonjolan atau sudutan ruang karena pada saat anak berkebutuhan khusus menunjukkan gejalanya biasanya melakukan hal-hal yang bisa membahayakan dirinya sendiri. Ruang harus nyaman, hangat dan tetap memperhatikan sirkulasi udara serta pencahayaan yang baik namun tetap aman tidak terjangkau oleh anak-anak. Dimensi ruang renung tidak boleh terlalu besar, agar penanganan oleh guru pendamping khusus lebih mudah, dan menciptakan komunikasi intim antara anak berkebutuhan khusus dengan guru pendamping lebih nyaman, hal ini akan membuat anak lebih cepat tenang. Faktor keamanan menjadi perhatian yang utama ketika anak sedang menunjukkan gejala khususnya, lantai ruang renung dilapisi dengan matras, jika anak-anak melompat-lompat atau berguling-guling tidak membahayakan fisiknya. 

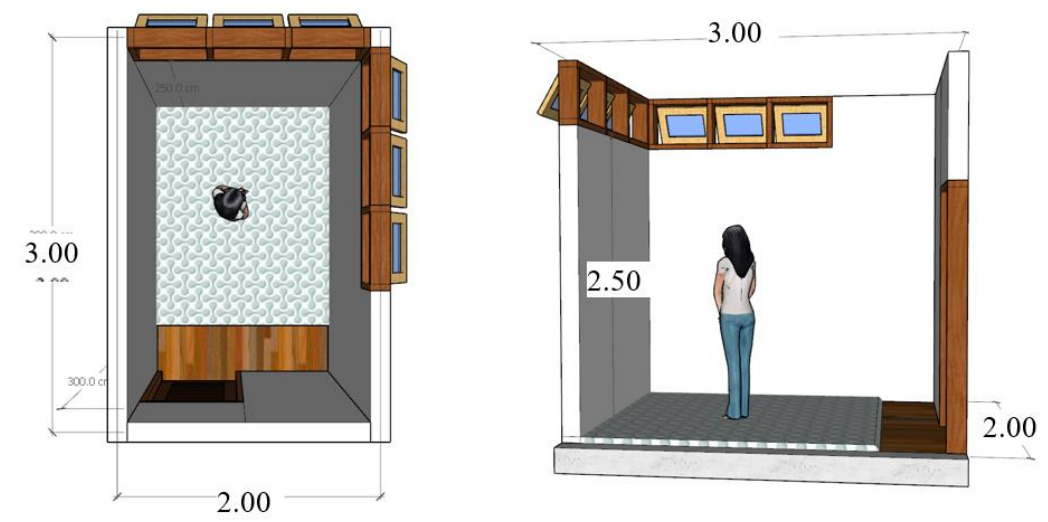

Gambar 3.3, Ruang Belajar Kelompok Kecil atau Individu Sumber : Hasil analisis, 2020

Kegiatan belajar tidak hanya disekolah tetapi dapat dilakukan dimanapun juga, diperlukan komunikasi yang baik dan personal tentang metoda pembelajaran, kemajuan ataupun kemunduran siswa. Komunikasi harus terjadi antara orang tua siswa, guru, psikolog dan pedagog, agar terciptanya pengetahuan dan perasaan yang sama terhadap anak berkebutuhan khusus. Tidak semua orang tua siswa mengetahui dan sadar tentang kondisi psikologis anak-anaknya, kondisi fisik dapat terlihat secara visual namun kondisi psikologis hanya dapat diketahui oleh orang mempelajari dan memiliki kualifikasi khusus tentang tumbuh kembang anak. Dalam proses penyampaian dengan orang tua siswa diperlukan Ruang Komunikasi atau Konsultasi yang nyaman dan suasana kekeluargaan. Suasana yang nyaman, akrab dan non formal dapat diciptakan dengan menempatkan tempat duduk yang nyaman berupa sofa yang lembut, sehingga orang tua dapat rileks. Ketika kondisi seseorang sudah dalam keadaan rileks dan nyaman, maka segala luapan perasaan, kekesalan, kesedihan dan emosi orang tua akan keluar dengan sendirinya. Kondisi tersebut tidak layak jika terlihat oleh orang lain, sehingga ruang konsultasi sebaiknya aman secara visual maupun audial dari orang lain. Sehingga ketinggian jendela dibuat setinggi 1,75 meter dari muka lantai, sehingga secara visual tidak terlihat dari luar namun kualitas cahaya dan udara ruang tetap terjaga dengan baik. Selain itu ruang konsultasi ditempatkan fasilitas layar atau TV besar yang digunakan untuk memutar rekaman video perkembangan aktivitas anak berkebutuhan khusus. (Gambar 3.4)
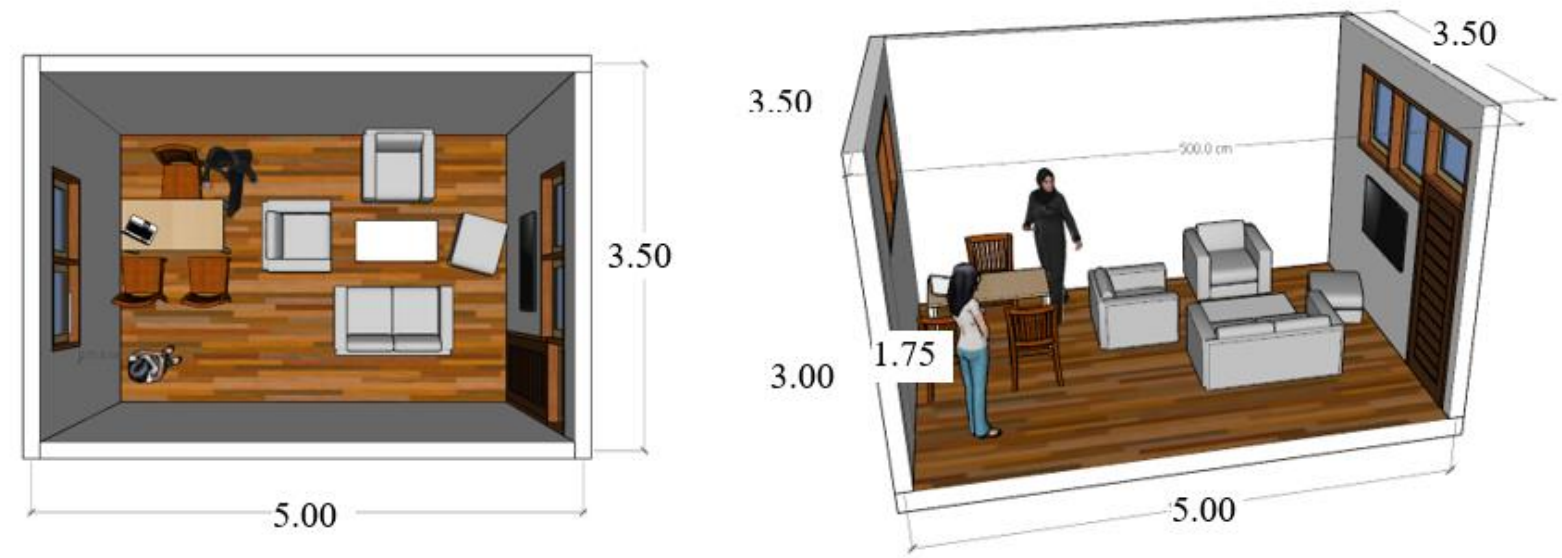

Gambar 3.4. Ruang Komunikasi atau Konsultasi Sumber : Hasil analisis, 2020 


\section{SIMPULAN}

Saat ini pemerintah belum mengeluarkan standar ruang untuk sekolah inklusi, selain ruang yang telah ditentukan sesuai standar pemerintah, sekolah inklusi juga memerlukan, ruang khusus yang digunakan sebagai penanganan anak berkebutuhan khusus. Ruang Belajar Individu yang digunakan untuk anak belajar bersama guru secara individual atau bisa juga secara kelompok dengan jumlah siswa terbatas, yaitu maksimum 5 siswa. Ruang Belajar Individu diperlukan karena bila anak berkebutuhan khusus (disabilitas) belajar di kelas, ia akan mengganggu teman-temannya dikelas. Ruang Renung atau Ruang Tenang. Ruang ini dibutuhkan untuk anak yang sedang mengamuk atau tantrum berat. Anak dibawa ke ruang tersebut agar tak mengganggu, agar tak ditiru ataupun agar tak di cemooh anak lain. Fungsi ruangan ini adalah agar anak berkebutuhan khusus dapat menenangkan dirinya, anak tersebut ditemani oleh seorang atau 2 orang guru. Ruang konsultasi dipergunakan untuk orang tua berkonsultasi dengan guru, psikolog dan pedagog di sekolah.

\section{UCAPAN TERIMA KASIH}

Kami ucapkan terima kasih kepada direktur Sekolah Binar Indonesia yang telah memberi kesempatan bagi kami untuk survey tentang anak berkebutuhan khusus di sekolah Binar Indonesia.

Selain itu, kami juga mengucapkan terima kasih kepada Direktur Stars Indonesia Academy yang telah memberikan masukan tentang ciri ciri anak berkebutuhan khusus.

\section{DAFTAR PUSTAKA}

[1] Friend, Marilyn \& William D. Bursuck. (2015). Menuju Pendidikan Inklusi: Panduan prkatis untuk mengajar. Yogyakarta: Pustaka Pelajar.

[2] Zaitun, (2017), "Pendidikan Anak Berkebutuhan Khusus", Kreasi Edukasi, Pekanbaru

[3] Direktorat Pendidikan Dasar, (2007). "Standar Sarana dan Prasarana Sekolah/Madrasah pendidikan Umum ",Peraturan menteri Pendidikan no 24 th 2007.

[4] Direktorat Pendidikan Anak Usia Dini, (2014). "Peraturan pendidikan Anak Usia Dini", Kementerian pendidikan Republik Indonesia.

[5] Laurens. Joyce M, (2004), Arsitektur dan Perilaku Manusia, Grasindo, Surabaya.

[6] Menteri Negara Lingkungan Hidup (1996), Keputusan Menteri Negara Lingkungan Hidup KEP-48/MENLH/11/1996, lingkungan/standar-kebisingan/

[7] Kementrian Pemberdayaan Perempuan dan Perlindungan Anak, (2013), Panduan Penanganan Anak Berkebutuhan Khusus Bagi Pendamping (Orang tua, Keluarga dan Masyarakat), Kantor Kementrian Pemberdayaan Perempuan dan Perlindungan Anak, Jakarta.

[8] Desiningrum. Dinie Ratri, (2004), Psikologi Anak Berkebutuhan Khusus, Psikosain, Yogyakarta.

[9] Riadin. Agung, dkk, (2017), Karakteristik Anak Berkebutuhan Khusus di Sekolah Dasar Negeri (Inklusi) di Kota Palangkaraya, Anterior Jurnal Volume 1, p-ISSN: 1412-1395; e-ISSN: 23553529

[10] Husna. Faiqatul. dkk (2019), Hak Mendapatkan Pendidikan Bagi Anak Berkebutuhan Khusus Dalam Dimensi Politik Hukum Pendidikan, Jurnal Sosial \& Budaya Syar-I FSH UIN Syarif Hidayatullah Jakarta Vol. 6 No. 2 (2019), pp.207-228, DOI: 10.15408/sjsbs.v6i1.10454 